\title{
EDITORIAL: 60 YEARS OF ACTA CARSOLOGICA: PAST, PRESENT, FUTURE
}

\author{
Franci GABROVŠEK ${ }^{1} \&$ Nataša RAVBAR ${ }^{1,2}$
}

\section{PAST}

Acta Carsologica was founded in 1955 by the Karst Research Institute of the Slovenian Academy of Sciences and Arts, based in Postojna. Initially the journal appeared sporadically, every three to four years. It was published when enough reports and papers, for the most part by Institute researchers, had accumulated.

At that time Acta Carsologica mainly published scientific papers and articles with karstological content, covering fields such as the geology, geomorphology and genesis of karst, speleological and speleobiological research, karst hydrogeological studies and archaeological findings from the cave sites, as well as brief reports on developments within the field and reviews of specialised literature. Geographically it was mainly limited to Slovenia and the Dinaric karst of Yugoslavia.

By the mid-1970s the journal had become a regularly published collection of scientific papers from the field of karstology, initially appearing every two years before becoming an annual publication in the 1980s. The papers published in the journal deepened theoretical knowledge about the nature of karst and advanced the direct transfer of knowledge into practice. Notable papers included significant speleological and hydrogeological research, particularly from Slovenia's Notranjska and Primorska regions, speleological studies related to the construction of motorways across the karst from Vrhnika to Sežana, speleological and hydrogeological research of Lake Cerknica and the surrounding area, the results of detailed geological mapping of the territory between Postojna, Planina and Cerknica, and systematic studies of cave sediments.

The journal was created primarily to promote knowledge and understanding of the Classical Karst, the area in SW Slovenia between Ljubljana and Trieste that hosts some of the globally most recognisable karst land- scape phenomena. With the passing years it has grown into a journal that not only fosters understanding of karstology and speleology at the local and global levels, but also offers an accessible forum for scientists, researchers, engineers and practitioners dealing with karst terrains.

It was with this aim that in 1974 Acta Carsologica compiled papers from the 6th Congress of Speleology, held in Sežana and Lipica in October 1972. In the 1980s the results of the work of the Karst Research Institute's researchers attracted growing interest among the specialist public both at home and abroad, which consequently triggered a strengthening of the international connections of Slovene karstologists.

For Acta Carsologica - and for the Karst Research Institute - the 1990s represented an increase in international cooperation and growing prestige. Many issues were devoted to specific topics or collaborations. In 1991, for example, the proceedings of a Slovene-French round table on Mediterranean mountain karst were published. In 1993 a special issue was published to mark the $500^{\text {th }}$ anniversary of the discovery of America, with contributions on the history of speleological exploration in the West Indies.

Since 1993 the Institute has organised the International Karstological School (IKS), which has become one of the world's largest annual scientific meetings dedicated to karst. Each year the IKS focuses on a specific topic and has provided a large number of relevant contributions to Acta Carsologica. To begin with Acta Carsologica published the proceedings of the IKS. Later, speakers at the IKS were invited to contribute manuscripts, which were then subjected to the standard peer-review procedure.

With the number of manuscripts growing, 1997 was the first year in which two issues of the journal were published. The first of these was devoted to karst hy-

\footnotetext{
${ }^{1}$ Karst Research Institute ZRC SAZU, Titov trg 2, SI-6230 Postojna, Slovenia, e-mail: Gabrovsek@zrc-sazu.si, natasa.ravbar@zrc-sazu.si

${ }^{2}$ Urban Planning Institute of the Republic of Slovenia, Trnovski pristan 2, SI-1127 Ljubljana, Slovenia
} 


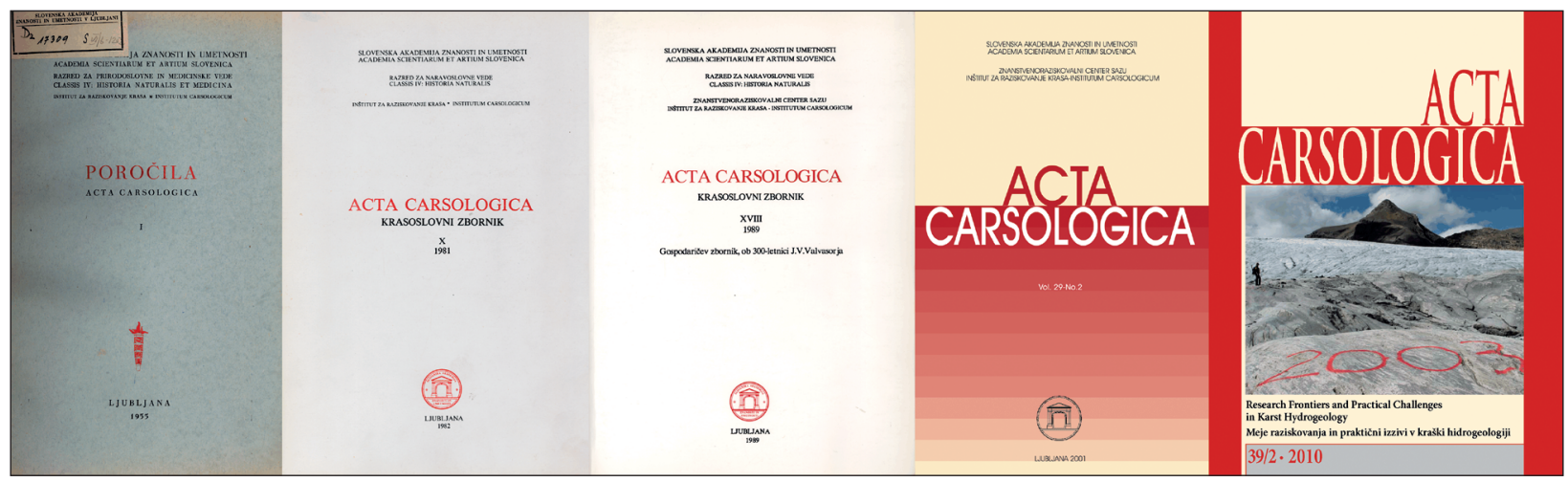

Fig. 1: Representative images of the Acta Carsologica journal over the past 60 years.

drogeological investigations in south-western Slovenia, while the second contained papers from the International Symposium on the History of Speleology and Karstology - ALCADI '96, held in Postojna.

The combination of regular and topical issues continued in the 2000s. Five topical issues were edited by high-profile guest editors. Acta Carsologica remains open to different initiatives, including the publication of topical issues.

In the 1990s the electronic version of Acta Carsologica was released. The oldest version of the website, with full open access to all papers, was launched in the mid-1990s and has been upgraded several times. A major upgrade, including a full redesign of the website, was carried out in 2006. Since then Acta Carsologica has been included in the Web of Science and Scopus databases.

The shift to electronic editing represented an important shift. After some consideration the Open Journal System (OJS) was selected as a platform for electronic publishing. This platform is used by over 8000 journals worldwide. Acta Carsologica is now edited and published within this platform.

\section{PRESENT AND FUTURE}

The team behind Acta Carsologica is a small one. In the past most of the work was done by the editor-in-chief and the assistant editor. This included all the administrative work relating to funding and publishing the journal, and even website maintenance. Acta Carsologica has never had a professional editor, secretary or other employee. All the work of the team has been done alongside regular research and teaching commitments. The lack of time available has, regretfully, sometimes resulted in submitted papers being processed slowly.

We believe that our enlarged team of acting editors (since 2014) will improve this situation, particularly once we have all got used to working within the OJS platform.

The world of science publishing is changing rapidly. Many journals appear and disappear, many are ab- sorbed by large publishing companies, and bibliometrics - though frequently criticised - have gained enormous importance. Authors expect their works to be published promptly and reviewers are hard to find.

Over the past 60 years the journal has earned a significant worldwide reputation and readership. Its peerreviewed research papers cover surface and subsurface karst geology, geomorphology, biology and the history of karst science, as well as geochemistry, geophysics, tectonics, numerical modelling, sociology and other disciplines.

We will continue to fight for the future of Acta Carsologica and do our utmost to ensure that access remains free and open. We count on the karst community to continue publishing good work in Acta Carsologica and to support us with thorough reviews. We will strive to improve the quality of papers while maintaining a policy that encourages the publication of works by young researchers and researchers from countries where karst science is still developing. We will probably remain small, but we hope to grow in the eyes of karst community.

In 2015 Acta Carsologica celebrated its $60^{\text {th }}$ anniversary of publication. The present issue is dedicated to an overview and synthesis of developments in karstology and speleology and to research frontiers in these and related fields of science.

The editors who have led the journal over the past 60 years are: Jovan Hadži (1955-1963), Srečko Brodar (1963-1974), Svetozar Ilešič (1974-1983), Rado Gospodarič (1983-1988), Peter Habič (1988-1993), Andrej Kranjc (1993-2010), Franci Gabrovšek (2010-present).

May we take this opportunity to thank to all past editors, members of the editorial board and advisory board, authors, reviewers, readers and those who provide financial support. We will continue to count on you in the future. 